\title{
PENGAYAAN PAKAN BENIH RAJUNGAN (Portunus Pelagicus) STADIA MEGALOPA MELALUI PEMBERIAN BETA KAROTEN
}

\author{
Rajungan (Portunus Pelagicus) Larvae Enhancement of Megalopa Stadia Through the Addition of Beta Carotene
}

\author{
Andi Yusneri ${ }^{1}$ Hadijah $^{2}$ dan Sutia Budi ${ }^{2}$ \\ ${ }^{1}$ Dinas Kelautan dan Perikanan Provinsi Sulawesi Selatan \\ ${ }^{2}$ Program Studi Budidaya Perairan Program Pascasarjana Universitas Bosowa
}

Email : andiyusneri1111@gmail.com

Diterima: 30 April 2020

Dipublikasikan: 05 Juni 2020

\begin{abstract}
ABSTRAK
Penelitian ini bertujuan untuk meningkatkan nilai nutrisi pakan alami rotifer dan artemia melalui penambahan beta karoten yang bersumber dari wortel. Penelitian ini dilaksanakan pada bulan Mei 2020 di unit pembenihan kepiting dan rajungan Balai Pe-rikanan Budidaya Air Payau (BPBAP) Takalar. Rancangan penelitian yang digunakan adalah rancangan acak lengkap (RAL) sebanyak 4 perlakuan dan 3 ulangan. Hewan uji yang digunakan adalah larva rajungan (Portunus Pelagicus) stadia megalopa yang ditebar dengan kepadatan 5 ekor/l dan dipelihara sampai memasuki stadia crab. Luaran penelitian yang ditargetkan adalah teknologi pengayaan pakan alami rotifer dan artemia menggunakan beta karoten yang berasal dari wortel. Hasil penelitian menunjukkan bahwa Pemberian frekwensi pakan yang tepat setelah dikayakan dengan beta caroten akan meningkatkan sintasan dan pertumbuhan pada larva rajungan. Frekwensi pakan yang tepat diberikan pada larva rajungan yang terbaik untuk kelang-sungan hidup larva rajungan adalah pemberian pakan 3 kali/hari.
\end{abstract}

Kata Kunci: Bata Karoten, Pengayaan, Rajungan, Wortel

\section{ABSTRACT}

This study aims to increase the nutritional value of natural rotifer and artemia feed by adding beta carotene from carrots. This research was conducted in May 2020 at the hatchery unit of the Brackish Water Cultivation Fishery Center (BPBAP) Takalar. The research design used was a completely randomized design (CRD) with 4 treatments and 3 replications. The experimental animals used were small crab larvae (Portunus pelagicus) in the megalopa stage which were stocked with a density of 5 individuals/l and they were kept until entering the crab stage. The target output of this research is natural feed enrichment technology for rotifer and artemia using beta carotene derived from carrots. The results showed that giving the right frequency of feed after being enriched with beta carotene would increase survival and growth in small crab larvae. The best frequency of feed given to small crab larvae for the survival of small crab larvae is feeding 3 times/day.

Keywords: Beta Carotene, Enrichment, Swimming Crab, Carrot

\section{PENDAHULUAN}

Rajungan merupakan salah satu komoditas ekspor perikanan penting dengan menempati posisi ke-3 terbesar setelah tuna dan udang. Nilai ekspor daging rajungan Indonesia pada tahun 2017 hampir mencapai USD 411 juta (KKP, 2018). Ekspor rajungan hingga saat ini masih mengandalkan tangkapan alam yang dilakukan terus menerus bahkan rajungan bertelur ikut tertangkap dan diolah. Hal ini dikhawatirkan akan mengakibatkan stok rajungan di alam semakin berkurang (Zaidin et al., 2013). Sebagai akibat dari penangkapan yang te-rus meningkat, menyebabkan populasi rajungan di alam dirasa semakin menipis terutama di daerah yang padat nelayannya seperti di Jawa dan Sulawesi Selatan. Untuk mengurangi eks-ploitasi rajungan melalui usaha penangkapan, maka upaya peningkatan produksi harus segera diarahkan pada usaha budidaya di tambak. Permintaan yang semakin tinggi akan daging rajungan (Portunus pelagicus) untuk memenuhi ke-butuhan tujuan ekspor ataupun lokal menuntut ketersediaan yang cukup dan berkesinambungan yang dapat dipenuhi dengan budidaya yang intensif.
Oleh karena itu diperlukan upaya untuk menghasilkan benih kepiting yang tepat kualitas, kuantitas maupun waktu, dengan memanfaatkan berbagai faktor yang diduga berpengaruh positif, antara lain dengan aplikasi pakan yang memenuhi standar nutrisi. Menurut Fulks et al, (1991) dalam Adi (2011), pakan merupakan komponen utama yang dibutuhkan oleh rajungan untuk menjaga kelangsungan hidup dan pertumbuhannya. Kelengkapan nutrisi dalam pakan mutlak diperlukan untuk menjaga agar pertumbuhan rajungan dapat berlangsung secara normal. Salah satu faktor yang penting dalam pemeliharaan larva adalah nutrisi pakan. Oleh karena itu larva harus diberi pakan dengan nutrisi yang tepat dan seimbang untuk mendapatkan tingkat sintasan yang optirnum (Aslianti et al., 1993).

\section{METODE PENELITIAN}

Penelitian ini dilakukan di unit pembenihan kepiting dan rajungan Balai Perikanan Budidaya Air Payau (BPBAP) Takalar. Tahapan penelitian diawali dengan penyediaan hewan 
uji berupa induk rajungan yang dipelihara di BPBAP Takalar. Selanjutnya penyediaan larva rajungan

Wadah penelitian menggunakan baskom plastik hitam bervolume $30 \mathrm{~L}$ sejumlah 12 buah yang telah diisi air laut bersalinitas 34 ppt- Wadah tersebut dilengkapi dengan peralatan aerasi sehingga dapat mempertahankan suhu media penelitian. Penempatan wadah tersebut dilakukan secara acak. Untuk mempertahankan kelarutan oksigen media, maka pada setiap wadah diberi aerasi lemah dengan menggunakan selang yang dihubungkan dengan pipet pasteur. Pakan yang digunakan dalam penelitian ini adalah dari pakan alami Rotifer dan nauplius artemia. Sebelum diberikan ke larva, rotifer dan artemia terlebih dahulu telah dikayakan dengan extrak wortel $\beta$-caroten 10 ppm selama 2-3 jam.

Padat penebaran larva megalopa sebanyak 5 ekor/ liter. Menurut Marjono, et al. (2002), faktor lain yang menyebabkan rendahnya sintasan larva rajungan (stadia megalopa) adalah naluri kanibalisme. Untuk mengurangi kanibalisme antara larva rajungan dengan mengatur padat penebaran awal, padat penebaran yang baik untuk larva sebanyak 3-5 ekor/liter. Pemberian pakan terdiri atas 4 perlakuan frekwensi pemberian pakan dengan 3 ulangan. Pemberian pakan pada perlakuan A dilakukan 2 kali sehari, perlakuan B dilakukan 3 kali sehari, pada perlakuan $\mathrm{C}$ dilakukan 4 kali sehari dan perlakuan $\mathrm{D}$ dilakukan 5 kali sehari. Peubah penelitian yang akan dilihat adalah;

\section{Survival Rate}

Menurut Effendi (2002), kelulushidupan merupakan prosentase kelulushidupan kultivan yang dapat dihitung dengan rumus sebagai berikut:

$$
\mathrm{SR}=\frac{\mathrm{N}_{\mathrm{t}}}{\mathrm{N}_{0}} \times 100 \%
$$

dimana:

$\mathrm{SR}=$ Sintasan $(\%)$,

$\mathrm{N}_{\mathrm{t}}=$ Jumlah hewan uji yang hidup pada akhir penelitian (ekor),

$\mathrm{N}_{\mathrm{o}}=$ Jumlah hewan Uji yang hidup pada awal penelitian (ekor).

\section{Pertumbuhan}

Untuk mengetahui laju pertumbuhan benih rajungan, maka dilakukan pengukuran pertumbuhan berat mutlak. Pengukuran dilakukan pada awal dan akhir penelitian. Pengukuran pertumbuhan menggunakan timbangan analitik dengan ketelitian 0.0001 gram. Pertumbuhan berat mulak dihitung sesuai metode Effendi, (1979) dengan menggunakan rumus :

$\mathrm{h}=W t-W o$

di mana :

$\mathrm{h}=$ Pertumbuhan berat mutlak (gram)

$W t=$ Rata-rata berat individu pada akhir pemeliharaan (gram)

Wo $=$ Rata-rata individu pada awal pemeliharaan $(\mathrm{g})$

\section{Rasio RNA/DNA}

Untuk mengukur konsentrasi DNA digunakan rumus yang digunakan Fatchiyah (2011) sebagai berikut :

[DNA] $=\AA 260 \times 50 \times$ Faktor pengenceran

dimana:

Å260= Nilai absorbansi pada $260 \mathrm{~nm}$

50 = Larutan dengan nilai absorbansi 1,0 sebanding dengan 50 ug untai ganda DNA per ml (dsDNA)
[RNA] $=\AA 260 \times 40$ x Faktor pengenceran

dimana $: 40=40 \mathrm{ug} / \mathrm{ml}$ untai tunggal RNA (ssRNA)

\section{Analisis Data}

Data penelitian dianalisis dengan menggunakan analisis ragam (ANOVA). Apabila terdapat pengaruh yang nyata maka dilanjutkan dengan uji lanjut W-Tuckey (Steel dan Torrie, 1993). Sebagai alat bantu untuk pelaksanaan uji statistik, digunakan paket perangkat lunak computer program SPSS.

\section{HASIL DAN PEMBAHASAN}

Berdasarkan Sintasan atau kelangsungan hidup didapatkan berdasarkan perbandingan antara jumlah larva rajungan stadia megalopa yang hidup pada akhir penelitian dengan jumlah larva yang ditebar pada awal penelitian. Pelaksanaan penelitian dibutuhkan waktu enam hari sampai semua larva rajungan stadia megalopa berubah menjadi stadia crab. Data rata - rata tingkat kelangsungan hidup larva rajungan dapat di lihat pada Tabel 1.

Tingkat kelangsungan hidup larva tertinggi terdapat pada perlakuan $\mathrm{B}$ frekwensi pemberian pakan $3 \mathrm{kali} / \mathrm{hari}$ $(41,56 \%)$, kemudian pada pemberian pakan 4 kali /hari $(38,00 \%)$, setelah itu pada pemberian pakan $2 \mathrm{kal} / \mathrm{hari}$ (34.00\%) dan yang terakhir terendah adalah pemberian pakan $5 \mathrm{kali} /$ hari $(30.44 \%)$.

Tingginya sintasan yang diperoleh pada perlakuan B diduga disebabkan karena ketersediaan pakan yang cukup dan tidak berlebihan yang mengakibatkan terjaganya faktor lingkungan dalam media pemeliharaan. hal ini bisa mendukung sintasan yang baik untuk larva rajungan. Menurut Effendy et al., (2005), bahwa pemberian pakan yang cukup memudahkan bagi larva mengambil dan makan pakan yang diberikan, sehingga kelangsungan hidup dapat bertahan.

Tabel 1. Data Rata -Rata Tingkat Kelangsungan Hidup Larva Rajungan

\begin{tabular}{c|c}
\hline Frekuensi Pakan (kali) & Sintasan (\%) \\
\hline 2 & $34,00 \pm 1,76$ \\
3 & $41,56 \pm 1,68$ \\
4 & $38,00 \pm 1,76$ \\
5 & $30,44 \pm 1,68$ \\
\hline
\end{tabular}

Rendahnya sintasan pada perlakuan D (5 kali/hari), diduga frekuensi pemberian pakan yang terlalu banyak sehingga menurut Susanto et al. (2005), bahwa pakan yang diberikan pada larva rajungan dalam jumlah yang berlebihan menyebabkan pakan tidak dimanfaatkan secara efesien. Sedangkan rendahnya sintasan pada perlakuan A ( 2 kali/hari), disebabkan karena frekuensi pemberian pakannya terlalu rendah dibanding dengan perlakuan B dan C, sehingga terjadi kanibalisme antara larva rajungan dan menyebabkan nilai sintasan menurun. Hal ini dipertegas Susanto dan Setyadi (2008), menyatakan bahwa sintasan larva rajungan yang bervariasi dipengaruhi oleh larva rajungan memiliki sifat kanibalisme yang akan memangsa larva lainnya. Sehingga kondisi ini sangat mempengaruhi persentase sintasannya. Lebih lanjut dinyatakan Marjono et al. (2002), bahwa rendahnya sintasan larva rajungan di sebabkan karena kanibalisme antara larva rajungan. 
Hasil sintasan yang diperoleh, tidak menunjukkan bahwa semakin besar sintasan yang diperoleh semakin besar pula hasil pertumbuhan mutlak larva rajungan, terlihat pada Tabel 2 perlakuan B $(41,56 \%)$ dan pada tabel 3.perlakuan A $(5,00 \%)$, dimana nilai sintasan tertinggi didapat dari perlakuan B dan pertumbuhan mutlak tertinggi pada perlakuan A. Hal ini diakibatkan dari dosis pakan alami yang merupakan salah satu faktor eksternal dalam menunjang pertumbuhan.

\section{Pertumbuhan}

Affandi dan Tang (2004), mengemukakan bahwa pertumbuhan adalah proses perubahan ukuran pada periode waktu tertentu. Data rata-rata pertumbuhan pada larva rajungan dapat dilihat pada Tabel 2.

Tabel 2. Rata-Rata Pertumbuhan Larva Rajungan

\begin{tabular}{c|c}
\hline Frekuensi Pakan (kali) & Pertumbuhan \\
\hline 2 & $5,00 \pm 0,01$ \\
3 & $4,73 \pm 0,03$ \\
4 & $3,82 \pm 0,02$ \\
5 & $4,37 \pm 0,33$ \\
\hline
\end{tabular}

Dari hasil penelitian terlihat tingkat pertumbuhan tertinggi pada perlakuan 2 kali pemberian pakan $(5,00)$, selanjutnya pada 3 kali pemberian pakan $(4,73)$, kemudian pada 5 kali pemberian pakan $(4,37)$ dan yang terendah 4 kali pemberian pakan $(3,82)$. Tingginya tingkat prtumbuhan pada 2 kali pemberian pakan diduga karena faktor kanibalisme. Hal ini dijelaskan dalam Moller et al. (2008), bahwa kanibalisme dapat secara langsung mempercepat pertumbuhan, biasanya larva yang berukuran lebih besar menempati tropik level yang lebih tinggi dibandingkan dengan larva yang lebih kecil. Sehingga memungkinkan dapat terjadinya kanibalisme apabila ukuran larva tidak seragam. Dan pernyataan Fatmawati (2009), bahwa pertumbuhan pada rajungan dipengaruhi oleh faktor jumlah dan ukuran makanan yang tersedia, umur, ukuran organisme, dan parameter kualitas air.

\section{Rasio RNA/DNA}

Rata-rata rasio RNA dan DNA pada larva rajungan yang telah diberi pakan setelah dikayakan dengan beta caroten dapat terlihat pada Tabel 3.

Tabel 2. Frekuensi Pakan Setelah Dikayakan Dengan Beta Caroten

\begin{tabular}{c|c}
\hline Frekuensi Pakan (kali) & Rasio RNA/DNA \\
\hline 2 & $0,84 \pm 0,04$ \\
3 & $0,78 \pm 0,02$ \\
4 & $0,75 \pm 0,04$ \\
5 & $0,76 \pm 0,04$ \\
\hline
\end{tabular}

Dari Tabel 3, memperlihatkan bahwa rasio RNA/DNA yang diperoleh tertinggi pada perlakuan frekwensi pakan 2 kali yaitu 0,84, kemudian frekwensi pakan 3 kali $(0,78)$ kemudian frekwensi pakan 5 kali $(0,76)$, dan terakhir terendah yaitu pada perlakuan frekwensi pakan 4 kali $(0,75)$.

Rasio RNA/ DNA dapat dijadikan sebagai parameter penilaian kualitas dari larva yang akan dibudidayakan . Budi (2017) menyatakan bahwa salah satu indikator pertumbuhan dan perkembangan organisme yaitu rasio RNA/DNA. Hal ini didukung oleh beberapa hasil penelitian seperti yang dilaporkan oleh Buckley (1979), bahwa terdapat korelasi positif antara laju pertumbuhan larva ikan Atlantic cod (Gadus morhua) dengan rasio RNA/DNA, dimana rasio RNA/DNA meningkat dengan meningkatnya laju pertumbuhan.

\section{Kualitas Air}

Kelayakan kualitas media perkembangan larva rajungan sangat berperan yang terdiri dari beberapa paremeter peubah fisika dan kimia meliputi suhu, salinitas, PH, DO dan amoniak dapat dilihat pada Tabel 4 dibawah.

Tabel 4. Paremeter Peubah Fisika dan Kimia

\begin{tabular}{lcccc}
\hline \multirow{2}{*}{ Parameter } & \multicolumn{4}{c}{ Frekuensi Pakan (Kali) } \\
\cline { 2 - 5 } & 2 & 3 & 4 & 5 \\
\hline Suhu $\left({ }^{0} \mathrm{C}\right)$ & $28-30$ & $29-31$ & $29-30$ & $28-30$ \\
Salinitas & & & & \\
$(\mathrm{ppt})$ & $32-33$ & $32-33$ & $32-33$ & $32-33$ \\
$\mathrm{pH}$ & $8,2-8,3$ & $8,2-8,3$ & $8,2-8,4$ & $8,2-8,4$ \\
DO (mg/L) & $4,9-5,5$ & $4,8-5,7$ & $4,9-5,5$ & $5,0-5,6$ \\
Amoniak & $0,004-$ & $0,004-$ & $0,005-$ & $0,005-$ \\
$(\mathrm{mg} / \mathrm{L})$ & 0,017 & 0,018 & 0,019 & 0,019 \\
\hline
\end{tabular}

Kualitas air dan pakan merupakan kriteria penting dalam pemeliharaan rajungan, jika keduanya tidak diperhatikan dengan serius, dikhawatirkan dapat terserang penyakit yang dapat mengakibatkan kematian pada larva. Suhu air sangat berpengaruh terhadap kelangsungan hidup rajungan dan organisme laut lainnya, dimana perubahan suhu sangat berpengaruh dalam kecepatan metabolisme dan kegiatan organisme lainnya. Perubahan faktor lingkungan seperti suhu, oksigen terlarut, salinitas dan mutu lingkungan air lainnya akan mempengaruhi frekuensi pergantian kulit dan peningkatan ukuran pada krustacea (Setyadi, 2008).

Suhu air selama penelitian berkisar antara $28-30{ }^{\circ} \mathrm{C}$, ini merupakan kisaran yang cukup baik untuk sintasan larva rajungan. Menurut Zaidin et al. (2013) suhu berpengaruh terhadap kelarutan gas dalam air dan proses metabolisme rajungan. Menurut Ikhwanuddin et al. (2012) suhu optimum untuk rajungan adalah $28-30^{\circ} \mathrm{C}$.

Nilai $\mathrm{pH}$ air selama penelitian berkisar antara 7-8. Kisaran ini masih optimal untuk pertumbuhan dan tingkat kelangsungan hidup larva rajungan. Menurut Syahidah (2003), bahwa $\mathrm{pH}$ 7,0-8,5 masih dalam batas normal untuk kehidupan larva rajungan stadia megalopa.

Kandungan amoniak yang terukur pada penelitian berkisar antara 0,004 - 0,019 ppm. Kisaran ini masih batas optimal bagi sintasan dan pertumbuhan larva rajungan. Menurut Ikhwanuddin, et al. (2012) kandungan amoniak optimal bagi sintasan dan pertumbuhan larva rajungan yaitu $<0,02 \mathrm{p}$

\section{KESIMPULAN}

Pemberian frekwensi pakan yang tepat setelah dikayakan dengan beta caroten akan meningkatkan sintasan dan pertumbuhan pada larva rajungan. Frekwensi pakan yang tepat diberikan pada larva rajungan yang terbaik untuk kelangsungan hidup larva rajungan adalah pemberian pakan 3 kali/hari, disarankan agar dalam pemberian pakan pada benih 
rajungan (Portunus pelagicus) sebaiknya dikayakan terlebih dahulu dengan beta caroten kemudian diberikan sebanyak 3 kali/hari

\section{DAFTAR PUSTAKA}

Adi, Y. S. 2011. Sintasan Larva Rajungan (Portunus pelagicus) Stadia Zoea pada Berbagai Frekuensi Pemberian Pakan Alami Jenis Brachionus plicatilis. Skripsi. Fakultas Pertanian, Universitas Muhammadiyah, Makassar. 46 hal.

Afandi dan Tang. 2004. Fisiologi Hewan Air. Badan Penerbit Universitas Riau. Pekan Baru. Riau. 215hal.

Aslianti, T., A. Prijono dan T. Ahrnad. 1993. Pcngaruh pemberian paliatr alatrti dar-r buatan t.erhadap kelangsungan hitltrp lalva bandeng, Clt'anos rhanos Forsskal. J. Penclitian Burlirlaya Pantai. I (1): 81- 90.

Buckley, K.J. 1979. Relationship Between RNA-DNA Ratio, Prey Density, and Growth Rate in Atlantic Cod (Gadus morhua) Larvae. Jurnal. Fish. Res. Board. Can. Vol. 30. 195-199 pp.

Budi, S. 2017. Pengaruh Suplementasi Asam Lemak Omega 3 danHormon Ecdyson Pada Pakan Alami Terhadap Performa Fisiologis Perkembangn dan Kelangsungan Hidup Larva Kepiting Bakau Scylla olivacea. Disertasi. Makassar. Program Pasca Sarjana- UNHAS. (Tidak Dipublikasikan).

Budi, S., \& Aslamsyah, S. (2011). Improvement of The Nutritional Value and Growth of Rotifer (Brachionus plicatilis) by Different Enrichment Period With Bacillus sp. Jurnal Akuakultur Indonesia, 10(1), 67-73.

Budi, S., \& Jompa, H. (2012, December). Pengaruh Periode Pengkayaan Rotifer Brachionus Plicatilis oleh Bacillus sp. Terhadap kualitas asam amino esensial. In prosiding forum inovasi teknologi akuakultur (pp. 599-603).

Budi, S., \& Zainuddin, Z. (2012). Peningkatan Asam Lemakrotifer Brachionus Plicatilis Dengan Periode Pengkayaan Bakteri Bacillus Sp. Berbeda. Octopus: Jurnal Ilmu Perikanan, 1(1), 1-5.

Effendi. 2002. Biologi Perikanan. Cetakan Kedua. Yayasan Pustaka Nusantara, Yogyakarta, 163 hlm

Effendie, M.I. (1979). Metode Biologi Perikanan. Yayasan Dewi Sri Bogor Indonesia, 122 pp.

Effendy, S., Faidar., Sudirman., E, Nurcahyono. 2005. Perbaikan TeknikPemeliharaan Larva Pada Produksi Masal Benih Rajungan Portunus pelagicus. Penelitian Balai Budidaya Air Payau Takalar 6: 1-10.

Fatmawati. 2009. Kelimpahan Relatif dan Struktur Ukuran Rajungan Di Daerah Mangrove Kecamatan Tekolabbua Kabupaten Pangkep.Skripsi. Jurusan Perikanan Fakultas Ilmu Kelautan dan Perikanan Universitas Hasanuddin, Makassar.

Ikhwanudin, Isnani. 2011. Pengaruh Persepsi Atribut Produk Terhadap Keputusan Pembelian Rokok Merek Gudang Garam Surya Professional Mild (Studi Kasus Pada Mahasiswa Jurusan Manajemen Angkatan 2011/2011 Fakultas Ekonomi Universitas Malang). Skripsi. Malang: Fakultas Ekonomi, Universitas Negri Malang.
Kementerian Kelautan dan Perikanan (KKP), 2018, Laporan Kinerja 2017.

Mardjono, M., L. Ruliaty., R. Prasetyo., dan Sugen. 2002. Pemeliharaan Larva Rajungan (Portunus pelagicus) Skala Massal. Balai Besar Pengembangan Budidaya Air Payau Jepara 3 (1): 1-9.

Moller H., S. Y Lee., B. Paterson and D. Mann. 2008. Cannibalism Contributes Significantly to the Diet of Cultured Sand Crabs (Portunus pelagicus Linn.): A Anal Stable Isotope Study. Journal Experimental Marine Biology and Ecology 37 (3): 75-82.

Setyadi,I. 2008. Pengaruh Suhu yang Berbeda terhadap Sintasan Larva Rajungan (Portunus pelagicus) di Wadah Terkontrol. Balai Besar Riset Perikanan Budidaya Laut Gondol Bali 7: 1-5.

Steel, R.G.D. dan J.H. Torrie. 1993. Prinsip dan Prosedur Statistika. PT Gramedia Pustaka Utama, Jakarta.

Susanto, Bambang., Irwan Setyadi., Heyanti., Adi Hanafi. 2005. Pedoman Teknis Teknologi Perbenihan Rajungan Portunus pelagicus. Pusat Riset Perikanan Budidaya. Jakarta. Hlm 2-17

Syahidah, D., B. Susanto, I. Setiadi., 2003. Percobaan Pemeliharaan Megalopa Rajungan, Portunus pelagicus Sampai Menjadi Rajungan Muda (Crablet 1) Dengan Kisaran Salinitas Berbeda. Balai Besar Riset Perikanan Budidaya Gondol 2: 1-6.

Zaidin, M. Z., Irwan. J. E dan Kadir S. 2013. Sintasan Larva Rajungan (Portunus pelagicus) Stadia Megalopa Melalui Kombinasi Artemia dan Branchionus plicatilis. Jurnal Mina Laut Indonesia. 1(1):112-121. 